
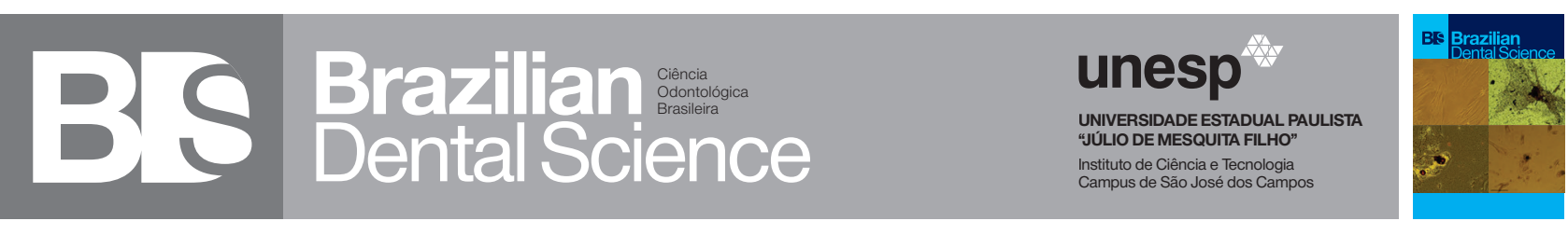

\title{
Analysis of adhesive bond strength under simulated pulpal pressure during laser irradiation on different dentin thicknesses
}

\author{
Análise da resistência adesiva sob pressão pulpar simulada durante irradiação laser em diferentes espessuras de dentina
}

Bruno do Amaral HADDAD ${ }^{1}$, Tânia Mara da SILVA ${ }^{1}$, Lucélia Lemes GONÇALVES ${ }^{1}$, Mateus Rodrigues SILVA ${ }^{1}$, Cláudio MOREIRA JUNIOR $^{1}$, Leandro Ruivo de SANTIS ${ }^{1}$, Sérgio Eduardo de Paiva GONÇALVES ${ }^{1}$

1 - Sao Paulo State University (Unesp) - Institute of Science and Technology, São José dos Campos - Department of Restorative Dentistry - São José dos campos - São Paulo - Brazil.

\begin{abstract}
Objective: Evaluate the microtensile bond strength ( $\mu$ TBS) in different dentin thicknesses, under simulated pulpal pressure (SPP), submitted to an adhesive technique using laser irradiation. Material and methods: Forty sound human molars were sectioned and randomly divided into two groups $(\mathrm{n}=20)$ : Group $1-1 \mathrm{~mm}$ of dentin thickness; Group $2-2 \mathrm{~mm}$ of dentin thickness. Each group was divided into two subgroups $(n=10)$ : Subgroup A - Absence of SPP; Subgroup P - Presence of SPP (15 $\left.\mathrm{cm} \mathrm{H}_{2} \mathrm{O}\right)$. The samples were sequentially treated with: $37 \%$ phosphoric acid, adhesive system (Adper Single Bond 2), Nd:YAG laser irradiation (60 s, 1064 nm, $10 \mathrm{~Hz}$ ) using 60 and $100 \mathrm{~mJ} /$ pulse energy parameters and photopolymerization (10 s). A composite resin block (Filtek Z350) was built up onto the irradiated area. After 30 days stored in water, the samples were sectioned and submitted to microtensile test (10 kgf load cell, $0.5 \mathrm{~mm} / \mathrm{min}$ ). Data were analyzed by twoway ANOVA and Tukey tests. Results: Two-way ANOVA revealed no significant differences for SPP on bond strength. The laser energy parameters indicated that $100 \mathrm{~mJ}$ showed greater $\mu$ TBS means compared to the group irradiated with $60 \mathrm{~mJ}$. The presence of SPP reduced the mean $\mu$ TBS values. Conclusions: Simulated pulpal pressure did not affect the $\mu$ TBS using $60 \mathrm{~mJ}$ of laser energy parameter. At $100 \mathrm{~mJ}$, the presence of SPP negatively influenced the bond strength, regardless of dentin thickness.
\end{abstract}

\section{KEYWORDS}

Bond strength; Dentin; Intrapulpal pressure; Nd:YAG laser.

\section{RESUMO}

Objetivo: O objetivo deste estudo foi avaliar a resistência adesiva (RA) em diferentes espessuras de dentina, associada à pressão pulpar simulada (PPS), quando submetidos à técnica adesiva por irradiação laser. Material e Métodos: Quarenta molares humanos hígidos foram seccionados e divididos aleatoriamente em dois grupos $(n=20)$ : Grupo 1 - $1 \mathrm{~mm}$ de espessura de dentina; Grupo $2-2 \mathrm{~mm}$ de espessura de dentina. As amostras foram divididas em 2 subgrupos $(n=10)$ : Subgrupo A - ausência de PPS; Subgrupo P - presença de PPS ( $15 \mathrm{~cm}$ de $\mathrm{H}_{2} \mathrm{O}$ ). As amostras foram tratadas seqüencialmente com: ácido fosfórico 37\%, sistema adesivo (Adper Single Bond 2), irradiação com Nd:YAG laser (60 s, $1064 \mathrm{~nm}, 10 \mathrm{~Hz}$ ) nos parâmetros de energia de 60 e $100 \mathrm{~mJ} /$ pulso e fotopolimerização (10 s). Um bloco de resina composta (Filtek Z350, 3M ESPE) foi confeccionado sobre a área irradiada. Após 30 dias armazenados em água, os espécimes foram seccionados e submetidos ao teste de microtração (carga de $10 \mathrm{kgf}$, $0.5 \mathrm{~mm} / \mathrm{min}$ ). Os dados foram analisados pelos testes ANOVA sob 2 fatores e Tukey $(\mathrm{p}<0.05)$. Resultados: ANOVA mostrou que não houve diferenças significativas para PPS na RA. Para os parâmetros de energia do laser, $100 \mathrm{~mJ}$ apresentou maiores médias de RA quando comparado ao grupo irradiado à $60 \mathrm{~mJ}$. A presença da PPS reduziu as médias de RA. Conclusão: Pressão pulpar simulada não afetou os valores de resistência adesiva para o grupo irradiado com $60 \mathrm{~mJ}$. Para $100 \mathrm{~mJ}$, a presença da pressão pulpar influenciou negativamente na resistência adesiva, independente das espessuras de dentina.

\section{PALAVRAS-CHAVE}

Resistência adesiva; Dentina; Pressão hidrostática; Nd:YAG Laser. 


\section{INTRODUCTION}

$\mathrm{T}$ he development and regular use of adhesive materials has revolutionized many aspects of restorative and preventive dentistry [1]. The adhesion mechanism to enamel and dentin is essentially an exchange process that involves the replacement of minerals removed from dental tissue, as a result of etching, by resin monomers with low surface tension and high diffusion capacity [2,3]. However, dentin bonding is a complex process and still represents a challenge, when considering morphological and structural differences at different depths [4] and moisture surface characteristics [5]. In an attempt to minimize the negative effects of excess moisture on adhesive procedures and standardize the morphology of hybridization zone, studies had been evaluated the effects of Nd:YAG (neodymium-doped yttrium aluminium garnet) laser irradiation on dental tissues [6-11].

The first applications of Nd:YAG laser on dentin surface resulted in decreased bond strength. The laser was applied to sound dentin prior to the adhesive system, resulting in heat denaturation of the organic components, as well as obliteration of the dentin tubules by melting and recrystallization of the inorganic components and low bond strength values $[6,10,12]$.

In 1999, Gonçalves et al.[6], through an in vitro study, developed the technique of Nd:YLF laser irradiation on dentin surface previously etched and impregnated by non-polymerized adhesive system. The authors obtained excellent bond strength results. Further studies had shown that laser irradiation technique significantly increases dentin bond strength, depending on laser energy parameters $[2,10,13]$. These greater results are due to the fusion and recrystallization of dentin in the presence of resin monomers, providing a more chemically environment for the adhesive process [6]. Laser also seems to optimize adhesion by improving evaporation of residual solvents [14].

Laser may raise the temperature of irradiated substrate, transmitting this heat to the pulp. This increase is directly proportional to the energy emitted by the laser and can result in irreversible damage. The literature believes that the temperature rise above $5,5^{\circ} \mathrm{C}$ in the pulp chamber represents a risk of pulpal necrosis [15], a fact that has been discussed by some researches due to the extreme conditions which these results were obtained, such as permanence time of the aggressor agent, intermittence or not of the heat application and pulp flow [16-18].

Simulated pulpal pressure effectively reproduces in vivo clinical conditions, allowing heat dissipation by renewing fluid within the pulp chamber. Silva et al. [13] observed a decrease in the variation of temperature when laser irradiation was performed in the presence of simulated pulpal pressure. Santis et al. [19] corroborated these results, also verifying the dentin thickness in 1 or $2 \mathrm{~mm}$ does not change the temperature differences observed at the pulp level. However, the presence of simulated pulpal pressure in relation to dentin thickness showed great influence in the reduction of the temperature. The question remains whether the same would occur in the bond strength.

Thus, the aim of this study was to evaluate the bond strength ( $\mu$ TBS) in different dentin thicknesses, under simulated pulpal pressure, submitted to an adhesive technique using laser irradiation. The null hypotheses were: (1) dentin thickness did not result in significant influence on $\mu \mathrm{TBS}$; (2) simulated pulpal pressure, during laser irradiation, did not result in significant influence on $\mu \mathrm{TBS}$; (3) laser energy parameters did not result in significant influence on $\mu$ TBS.

\section{MATERIAL AND METHODS}

\section{Samples preparation}

Forty sound human molars that were extracted for therapeutic reasons were used in this study, under approval of Research Ethical Committee at the São José dos Campos School of Dentistry (protocol number 283.030). The teeth were cleaned and stored in deionized water at $4^{\circ} \mathrm{C}$, for a maximum period of 30 days. 
The teeth were fixed into an acrylic holder using dental wax and sectioned using low-speed laboratory cutting machine (Labcut 1010, Extec Technologies Inc., Enfield, CT, EUA) under water cooling. The teeth were sectioned parallel to the occlusal surface to expose dentin and 1 $\mathrm{mm}$ below the enamel-cementum junction to separate crown from the roots and exposure the pulp chamber.

Tooth sample was taken to a polishing device (DP-10, Panambra, São Paulo, SP, Brasil), using 600-grit aluminum oxide abrasive disks, under water cooling, to standardize 20 samples with approximately $1 \mathrm{~mm}$ of dentin thickness, and 20 samples with approximately 2 $\mathrm{mm}$ thickness from the highest pulp horn.

In sequence, the tooth samples were randomly divided into two subgroups $(n=10)$, according to the presence or absence of simulated pulpal pressure (SPP). Each group was divided into other two subgroups $(n=5)$, based on Nd:YAG laser energy parameters (60 $\mathrm{mJ}$ and $100 \mathrm{~mJ}$ ).

\section{Simulated pulpal pressure}

For the group submitted to simulated pulpal pressure, the pressure device was adapted from the model proposed by Silva et al. [13]. The device had a reservoir filled with deionized water, placed $15 \mathrm{~cm}$ above the level of the pulp chamber.

\section{Restorative procedure}

The dentin surface was etched with $37 \%$ phosphoric acid A (Magic Acid, Coltene Vigodent SA Industria e Comercio, Rio de Janeiro, RJ, Brazil), for $15 \mathrm{~s}$ and rinsed. To remove excess water, the surface was gently dried with jets of air. The adhesive system (Adper Single Bond 2, 3M ESPE Dental Products, Saint Paul, MN, USA) was applied according to the manufacturer's instructions.

Before photopolymerization, the dentin surface impregnated with non-polymerized adhesive system was irradiated with Nd:YAG laser (Neodymium: Yttrium- AluminiumGarnet) Pulse Master 600 IQ (American Dental
Technologies, EUA), at wavelength of $1064 \mathrm{~nm}$ and a $320 \mu \mathrm{m}$ diameter of optical fiber [6]. The frequency of $10 \mathrm{~Hz}$ was applied using 60 and $100 \mathrm{~mJ}$ pulse of energy parameters [19]. Laser irradiation was applied in noncontact mode and with surface scanning for $60 \mathrm{~s}$ vertically and horizontally, similar to a stepping motor. During laser irradiation, the laser fiber tip was positioned at $90^{\circ}$ perpendicular to dentin surface and at a distance of $1 \mathrm{~mm}$. The laser irradiation was executed by the same calibrated operator.

In sequence, the adhesive system was photopolymerized (LED Light Curing System, Demi Plus, Kerr Corporation, Middleton, WI, USA), with power density of $1200 \mathrm{~mW} / \mathrm{cm}^{2}$, for $10 \mathrm{~s}$.

Composite resin blocks (4 $\mathrm{mm}$ diameter and $2 \mathrm{~mm}$ height) were built up on the irradiated dentin surface. Composite resin (Z350 XT, 3M/ ESPE, St Paul, MN, USA) was inserted in two increments of about $2 \mathrm{~mm}$ each, with each increment photopolymerized for 20 s (LED Light Curing System, Demi Plus, Kerr Corporation, Middleton, WI, USA). All restored samples were stored in deionized water for 30 days, at $37^{\circ} \mathrm{C}$.

\section{Microtensile bond strength ( $\mu$ TBS)}

After 30 days, the samples restored were sectioned using a laboratory cutting machine (Labcut 1010, Extec Technologies Inc., Enfield, CT, EUA) to obtain dentin-composite resin sticks $\left(1 \mathrm{~mm}^{2}\right)$. The sticks were stored in individual and identified vials (Eppendorf, São Paulo, SP, Brasil) at $37^{\circ} \mathrm{C}$, containing deionized water for $24 \mathrm{~h}$, before testing.

The microtensile bond strength test was performed in a universal testing machine (EMIC DL-1000, São José dos Pinhais, PR, Brazil) at a crosshead speed of $0.5 \mathrm{~mm} / \mathrm{min}$ and using a $10 \mathrm{~kg}$ load cell. The mean value (in $\mathrm{MPa}$ ) for the sticks originating from each tooth was calculated and used for the statistical analysis.

\section{Statistical analysis}

Data were analyzed by two-way ANOVA (pulpal pressure, laser energy) according to dentin thickness ( $1 \mathrm{~mm}$ and $2 \mathrm{~mm}$ ), followed by Tukey test $(\alpha=5 \%)$. 


\section{RESULTS}

According to the two-way ANOVA (Table 1), laser energy parameters significantly affected ( $p<0.05$ ) the bond strength in the group of $1 \mathrm{~mm}$ of dentin thickness. The interaction ( $\mathrm{p}=0.4985)$ and the simulated pulpal pressure showed no significant differences $(p=0.2653)$ in the bond strength, under the experimental conditions.

Table 1- Two-way ANOVA for $1 \mathrm{~mm}$ of dentin thickness.

\begin{tabular}{|cccccc|}
\hline Source & DF & SS & MS & F & $p$ \\
\hline Laser & 1 & 3024 & 3024 & 55.97 & $0.0001^{\star}$ \\
\hline Pulpal Pressure (SPP) & 1 & 72.33 & 72.33 & 1.339 & 0.2653 \\
\hline Interaction & 1 & 26 & 26 & 0.4812 & 0.4985 \\
\hline Residual & 15 & 810.4 & 54.03 & & \\
\hline
\end{tabular}

* Statistically significant differences $(p<0.05)$.

When considering the laser energy parameters ( $\mathrm{p}<0.0001)$, the highest bond mean values was observed in the group irradiated with $100 \mathrm{~mJ}$ and restored in the absence of SPP $(49.61 \pm 9.59)^{\mathrm{Ab}}$. For the group irradiated with $60 \mathrm{~mJ}$, there were no significant differences between the presence or absence. However, it differed significantly from the group irradiated with $100 \mathrm{~mJ}$ (Table 2).

Table 2 - Group: $1 \mathrm{~mm}$ of dentin thickness. Means $( \pm \mathrm{SD})$ of the bond strength (MPa) and the Tukey results (5\%).

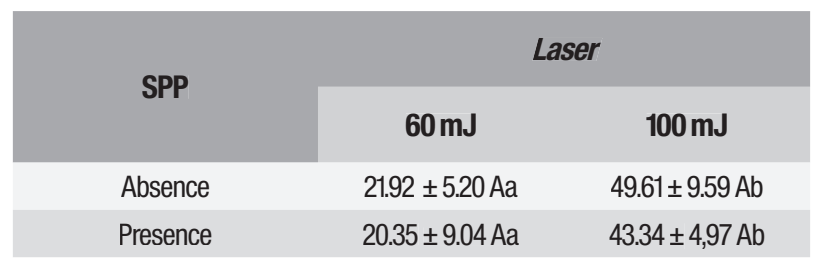

${ }^{*}$ Different letters show statistically significant differences $(p<0.05)$; capital letters refer to columns; lowercase letters refer to lines.

In the group of $2 \mathrm{~mm}$ of dentin thickness, two-way ANOVA (Table 3) showed laser energy parameters and the interaction between Laser and SPP significantly affected ( $\mathrm{p}<0.05$ ) the bond strength. The simulated pulpal pressure showed no significant differences $(\mathrm{p}=0.2817)$ in the bond strength, under the experimental conditions.
Table 3 - Two-way ANOVA for $2 \mathrm{~mm}$ of dentin thickness.

\begin{tabular}{|cccccc|}
\hline Source & DF & SS & MS & F & $\boldsymbol{p}$ \\
\hline Laser & 1 & 3945 & 3945 & 153.5 & $0.0001^{*}$ \\
\hline Pulpal Pressure (sPP) & 1 & 31.9 & 31.9 & 1.241 & 0.2817 \\
\hline Interaction & 1 & 425.4 & 425.4 & 16.55 & $0.0009^{*}$ \\
\hline Residual & 16 & 411.3 & 25.71 & & \\
\hline
\end{tabular}

* Statistically significant differences $(p<0.05)$.

When considering the interaction of laser energy parameters and simulated pulpal pressure ( $\mathrm{p}=0.0009)$, the highest bond mean values was observed in the group irradiated with $100 \mathrm{~mJ}$ and restored in the absence of SPP $(55.59 \pm 6.82)^{\mathrm{Ab}}$, with significantly statistical difference from the group restored in the presence of SPP $(43.84 \pm 3.63) \mathrm{Bb}$. For the group irradiated with $60 \mathrm{~mJ}$, there were no significant differences between the presence or absence. However, it differed significantly from the group irradiated with $100 \mathrm{~mJ}$ (Table 4).

Table 4 - Group: $2 \mathrm{~mm}$ of dentin thickness. Means ( \pm SD) of the bond strength (MPa) and the Tukey results (5\%).

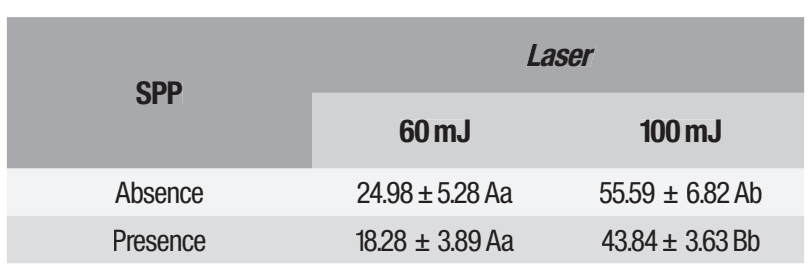

*Different letters show statistically significant differences $(p<0.05)$; capital letters refer to columns; lowercase letters refer to lines.

When considering the interaction of laser energy parameters and simulated pulpal pressure $(\mathrm{p}=0.0088)$, the highest bond mean values was observed in the group irradiated with $100 \mathrm{~mJ}$ and restored in the absence of SPP $(56.0 \pm 12.4)^{\mathrm{A}}$. For the group irradiated with $60 \mathrm{~mJ}$, there were no significant differences between the presence or absence. However, it differed significantly from the group irradiated with $100 \mathrm{~mJ}$ (Table 2). 


\section{DISCUSSION}

Adhesive systems are composed of resinous monomers of different viscosities and organic solvents (ethanol, acetone, water), and are commercially available in different compositions, mechanisms of action and application forms [3,20,21].

The bonding mechanism of adhesive systems to the dentin substrate is still considered complex, when compared to the enamel substrate, because it has a heterogeneous composition, consisting of organic and inorganic components, different proportions of peritubular, intertubular and sclerotic dentin, variations in permeability and communication with the pulpal tissue. These properties may directly or indirectly affect substrate bond strength [4,6,22-28].

To remedy such difficulties, changes in adhesive systems composition and adhesive techniques have been proposed. Regarding composition, new comonomers, hydrophilic and hydrophobic photoinitiators combinations, remineralizing bioactive particles, MMP inhibitors and crosslinkers are observed [2731]. Among the techniques are ethanol wetbonding [5], collagen fixatives [32] and the use of various forms of laser energy to treat dental tissues, such as Neodymium [33-38].

The original idea of using the Neodymium laser after applying the adhesive system prior to polymerization, came from the work of Gonçalves et al. [33]. The authors concluded that Nd:YLF laser, in the parameters employed, promoted the fusion and resolidification of dentin hydroxyapatite in the presence of resinous monomers, suggesting the creation of a new hybridization modality, proven by X-ray diffraction and SEM; corroborated by Franke et al. [10] with significant improvement in hybridization quality and, Silva et al. [39] even in the presence of simulated pulpal pressure.

As the objective of this study was to evaluate the bond strength to human dentin submitted to Nd:YAG laser irradiation, the standardization of the remaining dental was fundamental. Dental remnant thickness standardization was performed from the highest pulpal horn. Thus, specimens with 1 $\mathrm{mm}$ of dentin thickness were used $[25,26,40]$ and also with $2 \mathrm{~mm}$ [41].

Based on the study by Santis et al. [19], this study used simulated pulpal pressure to approach "in vivo" conditions. The results of this study demonstrate that the adhesive Adapter Single Bond 2 (3M ESPE) is sensitive to dentin moisture produced by pulpal pressure simulation, just as other adhesives used in previous studies, as there was a decrease in adhesive strength when compared to restored groups without pulpal pressure [39].

Positive results obtained by laser irradiation of the adhesive system, prior to photopolymerization, may be related to the improvement in the degree of conversion of the systems [11], as well as higher solvent evaporation by increasing surface temperature during irradiation [42], besides the morphological modifications of the adhesive interface as reported by Gonçalves et al. [33].

Laser irradiation at the $100 \mathrm{~mJ}$ parameter positively influenced the microtensile bond strength. In this study, a significant increase in adhesive strength was observed with the increase in laser intensity, contrary to the results obtained by Franke et al. [10], and according to what was found by Silva et al.[39], Marimoto et al. [37] e Ribeiro et al. [43].

Although the $60 \mathrm{~mJ}$ parameter provides lower adhesive strength values than the 100 $\mathrm{mJ}$ parameter, such results approximate those in the control group (without laser) in the presence of simulated pulpal pressure from the study by Silva et al. in 2016 [39]. As laser can improve the degree of conversion of adhesive systems, this result may be reflected in better longitudinal behavior of hydrolytic degradation resistance[11]. Positive results with $100 \mathrm{~mJ}$ may also offer better longitudinal perspectives, contrary to the results by Barcellos 
et al. (2016) [44] that used higher energy, verifying greater longitudinal degradation of collagen fibers with the parameter of $120 \mathrm{~mJ}$.

The non-use of a control group without laser was an option in this study because it has already been analyzed in several studies of this research group, considering that it would constitute another complicating factor of the statistical understanding of the results. Regardless dentin thicknesses, the laser energy parameters and the presence of pulpal pressure influenced the bond strength results, so that the largest parameter positively influenced the means bond values and the presence of pulpal pressure negatively, reducing the values.

The safety in the applicability of the technique in terms of temperature elevation, in the parameter used, was also ratified in the studies by Santis et al. [19] and Silva et al. [39], where, with the parameter $100 \mathrm{~mJ}$ and presence of pulpal pressure, no critical pulpal temperature elevations were observed.

Thus, in vivo research can now be made possible to confirm these results, in order to clinically prove the positive effects of the Nd:YAG laser adhesive technique, as laboratory research has confirmed the safety of the technique and its beneficial effects to the adhesive process.

\section{CONCLUSION}

Within the limitations of the study, it can be inferred that the dentin bond strength on the adhesive system under laser irradiation and pulpal pressure:

(1) No significant influence of dentin thickness;

(2) Positively interfered with the increase of laser energy parameters;

(3) Negatively influenced by the presence of simulated pulpal pressure.
1. Sofan E, Sofan A, Palaia G, Tenore G, Romeo U, Migliau G. Classification review of dental adhesive systems: from the IV generation to the universal type. Ann Stomatol (Roma) 2017;8:1-17.doi:1011138/ads/2017.81.001.

2. Marimoto A, Cunha L, Yui K, Huhtala M, Barcellos D, Prakki A, et al. Influence of Nd:YAG Laser on the Bond Strength of Self-etching and Conventional Adhesive Systems to Dental Hard Tissues. Oper Dent 2013;38:447-55. doi:10.2341/11383-L.

3. Gonçalves SEP, Cruz N, Brayner R, Huhtala MFRL, Borges AB, Barcellos DC Grander system: A new technology to reduce surface tension of adhesive systems in dentistry. Acta Odontol Scand 2014;72:31-5. doi:10.3109/00016357 2013.794953.

4. Anido-Anido A, Amore R, Lewgoy HR, Anauate-Netto C. Comparative study of bond strength to human and bovine dentine at three different depths. Brazilian DentSci 2012;15:4-10. doi:10.14295/bds.2012.v15i2.786.

5. SadekFT,Braga RR, Muench A, Liu Y,Pashley DH, Tay FR. Ethanol Wet-bonding Challenges Current Anti-degradation Strategy.J Dent Res 2010;89:1499-504. doi:10.1177/0022034510385240.

6. Goncalves SE, de Araujo MA, Damiao AJ. Dentin bond strength:influence of laser irradiation, acid etching, and hypermineralization. J Clin Laser Med Surg 1999;17:77-85.

7. MATOS AB,OLIVEIRADC, KURAMOTOM, de PAULA EDUARDOC,MATSONE Nd:YAG Laser Influence on Sound Dentin Bond Strength. J Clin Laser Med Surg 1999;17:165-9. doi:10.1089/clm.1999.17.165.

8. Matos AB, Oliveira DC, Navarro RS, de Eduardo CP,Matson E. Nd:YAG laser influence on tensile bond strength of self-etching adhesive systems. JClin Laser Med Surg 2000;18:253-7.doi:10.1089/clm.2000.18.253.

9. Araujo RM, de PaulaEduardo C, Duarte Junior SLL, Araujo MAM, de Castro Monteiro Loffredo L Microleakage and Nanoleakage: Influence of Laser in Cavity Preparation and Dentin Pretreatment. J Clin Laser Med «html_entGlyph="@amp;" Ascii="\&amp;"'»Surg 2001;19:325-32. doi:10.1089/104454701753342785.

10. Franke M, Taylor AW, Lago A, Fredel MC. Influence of Nd:YAG Laser Irradiation on an Adhesive Restorative Procedure. Oper Dent 2006;31:604-9. doi:10.2341/05-110

11. Brianezzi LFR, Maenosono RM, Bim Júnior 0,Zabeu GS, Palma-dibb RG, IshikiriamaSK. Does laser diode irradiation improve the degree of conversion o f simplified dentin bonding systems ? J Appl Oral Sci 2017;25:381-6.

12. Matos AB, Oliveira DC, Kuramoto M, Eduardo CP,Matson E. Nd:YAG laser influence on sound dentin bond strength. J Clin Laser Med Surg 1999;17:165-9. doi:10.1089/clm.1999.17.165.

13. Silva TM, Gonçalves LL, Fonseca BM, Esteves SRMS, Barcellos DC, Damião AJ, etal. Influence of Nd:YAG laser on intrapulpal temperature and bond strength of human dentin under simulated pulpal pressure. Lasers Med Sci 2016. doi:10.1007/s10103-015-1827-1

14. Barcellos D, Batista G, Pucci C,Persici E, Borges A, Torres C, etal. Longitudinal Evaluation of Bond Strength to Enamel of Dental Adhesive Systems Associated with Nd:YAG Laser. Oper Dent 2015;40:E122-31. doi:10.2341/13181-L.

15. Zach L, Cohen G. Pulp response to externally applied heat. Oral Surgery, Oral Med Oral Pathol 1965;19:515-30. doi:10:1016/0030-4220(65)90015-0.

16. Zarpellon DC, Runnacles P,Maucoski C, Coelho U, Rueggeberg FA, Arrais C. Controlling In Vivo, Human Pulp Temperature Rise Caused by LED Curing Light Exposure. Oper Dent2019;44:235-41. doi:10.2341/17-364-C.

\section{REFERENCES}


17. Zarpellon DC, Runnacles P,Maucoski C,Gross DJ, Coelho U, Rueggeberg FA, et al. Influence of Class V preparation on in vivotemperature rise in anesthetized human pulpduring exposure to a Polywave LED light curingunit. Dent Mater 2018:34:901-9.

18. Runnacles P,Arrais CAG, Pochapski MT, Santos FA, Coelho U, Gomes JC, et al. In vivo temperature rise in anesthetized human pulp during exposure to a polywave LED light curing unit. Dent Mater 2015;31:505-13. doi:10.1016/j. dental.2015.02.001.

19. Santis LR, Silva TM, Haddad BA, Gonçalves LL, Gonçalves SEP.Influence of dentin thickness on intrapulpal temperature under simulated pulpal pressure during Nd:YAG laser irradiation. Lasers Med Sci 2017. doi:10.1007/s10103-0162098-1.

20. Carvalho R, Carrilho M,Pereira L. Sistemas adesivos: Fundamentos para aplicação clínica. Biodonto. 2.1-89. Biodonto 2004,2:1-89.

21. Oliveira N, Diniz L, Svizero N, D’Alpino P,Pegoraro C. Dental adhesives: new concepts and clinical applications. Rev Dent Line 2010;9:6-14.

22. Pashley EL, Himer JA, Liu M, Kim S, Pashley DH. Effects of CO 2 laser energy on dentin permeability. J Endod 1992;18:257-62. doi:10.1016/S00992399(06)80951-9.

23. Escribano N, Del-Nero 0,Macorra JCD La. Sealing and dentin bond strength of adhesive systems in selected areas of perfused teeth. Dent Mater 2001;17:14955. doi:101016/S0109-5641(00)00057-9.

24. Özok AR, Wu M, Gee AJDe, Wesselink PR. Effect of dentin perfusion on the sealing ability and microtensile bond strengths of a total-etch versus an all-inone adhesive. DentMater 2004;20:479-86. doi:10.1016/j.dental.2003.07.004 .

25. Hosaka K, Nakajima M, Yamauti M, Aksornmuang J, Ikeda M, Foxton RM, etal. Effect of simulated pulpal pressure on all-in-one adhesive bond strengths to dentine.J Dent2007;35:207-13. doi:10.1016/j.jdent.2006.08.001.

26. Sauro S, Pashley DH, Montanari M, Chersoni S, Carvalho RM, Toledano $M$, etal. Effect of simulated pulpal pressure on dentin permeability and adhesion of self-etch adhesives. Dent Mater 2007;23:705-13. doi:10.1016/j. dental.2006.06.010

27. Barcellos DC, Fonseca BM, Pucci CR, Cavalcanti BDN, Persici EDS, De Paiva Goncalves SE.Zn-doped etch-and-rinse model dentin adhesives: Dentin bond integrity, biocompatibility, and properties. Dent Mater 2016;32:940-50. doi:10.1016/j.dental.2016.04.003.

28. Fonseca BM, Barcellos DC, Silva TM da, Borges ALS, Cavalcanti BN, Prakki A, et al. Mechanical-physicochemical properties and biocompatibility of catechinincorporated adhesive resins. J Appl Oral Sci 2019;27:1-11. doi:101590/16787757-2018-0111.

29. Torres GB, da Silva TM, Basting RT, Bridi EC, França FMG, Turssi CP,etal. Resin-dentin bond stability and physical characterization of a two-step selfetching adhesive system associated with TiF«inf»»«/inf». Dent Mater 2017;33. doi:10.1016/j.dental.2017.07.016.

30. Hebling J,Pashley DH, TJäderhane L, Tay FR. Subclinical Degradation of Dentin Hybrid Layers in vivo. J Dent Res 2005;84:741-6.
31. Zhou J, Chiba A, Scheffel DLS, Hebling J, Agee K, Tagami J, et al. Cross-linked dry bonding: A new etch-and-rinse technique. Dent Mater 2016;32:1124-32. doi:10.1016/j.dental.2016.06.014.

32. Hebling J, Pashley DH, Tjäderhane L, Tay FR. Chlorhexidine arrests subclinical degradation of dentin hybrid layers in vivo. J Dent Res 2005. doi:10.1177/154405910508400811.

33. Gonçalves SEP, de Araujo MA, Damião AJ. Dentin bond strength: influence of laser irradiation, acid etching, and hypermineralization. J Clin Laser Med Surg 1999;17:77-85.

34. Seino PY,Freitas PM, Marques MM, de Souza Almeida FC, Botta SB, Moreira MSNA. Influence of CO2 $(10.6 \mu \mathrm{m})$ and Nd:YAG laser irradiation on the prevention of enamel caries around orthodontic brackets. Lasers Med Sci 2015;30:611-6. doi:10.1007/s10103-013-1380-8.

35. White JM, Fagan CM, Goodis HE.Pulsed Nd:YAG Laser Treatment Intrapulpal Temperatures During of Dentin, In Vitro. J Periodontol 1994;65:255-9.

36. Matos AB, Oliveira DC, Navarro RS, Eduardo CDEP,Matson E. Nd: YAG Laser Influence on Tensile Bond Self-Etching Adhesive Systems Strength of. JClin Laser Med Surg 2000;18:253-7.

37. Marimoto A, Cunha L, Yui K, HuhtalaM,Barcellos D, Prakki A, etal. Influence of Nd:YAG Laser on the Bond Strength of Self-etching and Conventional Adhesive Systems to Dental Hard Tissues. Oper Dent 2013;38:447-55. doi:10.2341/11383-L

38. Spencer P,Ye Q, Misra A, Goncalves SEP, Laurence JS. Proteins, pathogens, and failure at the composite-tooth interface.J Dent Res 2014;93:1243-9. doi:10.1177/0022034514550039.

39. Silva TM, Gonçalves LL, Fonseca BM, Esteves SRMS, Barcellos DC, Damião AJ, etal. Influence of Nd:YAG laser on intrapulpal temperature and bond strength of human dentin under simulated pulpal pressure. Lasers Med Sci 2016;31:49-56. doi:10.1007/s10103-015-1827-1.

40. Cardoso MV,Moretto SG, Eliza MAR. Influence of intrapulpal pressure simulation on the bond strength of adhesive systems to dentin Rubens Côrte Real de Carvalho MSc Student. Braz Oral Res 2008;22:170-5.

41. Belli R, Sartori N,Peruchi LD, Guimarães JC, AraújoÉ, Monteiro S, etal.Slow progression of dentin bond degradation during one-year water storage under simulated pulpal pressure.J Dent 2010;38:802-10. doi:10.1016/j. jdent.2010.06.012

42. Batista GR, Barcellos DC, Torres CRG, Damiao AJ, Oliveira HP, Gonçalves SEP. Effect of Nd:YAG laser on the solvent evaporation of adhesive systems. Int J EsthetDent 2015;10:598-609.

43. Ribeiro CF,Anido AA, Rauscher FC, Yui KCK, Gonçalves SEDP.Marginal leakage in class $V$ cavities pretreated with different laser energy densities. Photomed Laser Surg 2005;23:313-6. doi:10.1089/pho.2005.23.313.

44. Barcellos DC, Batista GR, Persici Ede S, Pucci CR, Huhtala MFR, Lima, etal.Can Nd:YAG laser irradiated on dentin with non-polymerized adhesives influence the durability of bond strength and micromorfology of hybrid layer? Brazilian Dent Sci 2016;19:23-33. doi:10.14295/bds.2016.v19i1.1173.

\section{Tânia Mara da Silva}

(Corresponding address)

Avenida Engenheiro Francisco José Longo, 777, Jardim São Dimas, São José dos

Campos, SP, Brazil, CEP: 12245-000.

Date submitted: 2019 Aug 30

E-mail: taniamara.odonto@gmail.com 